to another, the only services required being electricity and water. Safety precautions are such that whether the plant is switched off, the current interrupted involuntarily, or the water supply interrupted, it is not possible for dangerously high pressures to develop in any part of the system.

\section{International Conference on Soil Mechanics and Foundation Engineering}

THE Second International Conference on Soil Mechanics and Foundation Engineering is to be held in Rotterdam during June 2l-30, 1948, on the invitation of the Netherlands Government and the Municipality of Rotterdam. The following subjects have been selected for discussion: (A) Technical and Scientific Topics : theories, hypotheses, considerations of general character ; investigations in the laboratory and in the field ; stability and deformation of earth and earth constructions; stability and movements of soilretaining constructions; stress distributions under foundations and settlements of structures ; pile foundations, pile loading tests; problems in highway and runway constructions (superstructure) ; methods for improving the mechanical quality of soils; groundwater movements. (B) Topics of a General Character : survey of the existing institutions and individuals working in the sphere of soil mechanics; suggestions for international co-operation. Anyone interested in the Conference, whether from the point of view of practical application, research or teaching, is welcome to attend the meetings and to contribute reports or discussions. The president of the Conference is Prof. K. Terzaghi and the secretary Prof. A. Casagrande. An organising committee has been appointed under the chairmanship of Ir. J. P. van Bruggen, with Ir. T. K. Huizinga as secretary and Ir. W. C. van Mierlo as treasurer. The Institution of Civil Engineers has convened a British National Committee under the chairmanship of Mr. W. K. Wallace, and full particulars of the Conference can be obtained from the Secretary, Institution of Civil Engineers, Great George Street, London, S.W.1.

\section{American Philosophical Society Publications}

The Amorican Philosophical Society has issued reports of two symposia held last year at Philadelphia (Proc. Amer. Phil. Soc., 90, No. $4 ; 1946$ ), both of very general and vital interest, one of them on "Present Day Social and Economic Aspects of National Health" and the other on "U.N.E.S.C.O. and American Participation in its Activities". As to the first of these symposia, it is obviously profitable to compare notes with the United States on the health of the people, on the role of Government agencies in a national health programme, and on the place of the physician in modern society. The other symposium is of great value as giving a comprehensive view of the United Nations Educational, Scientific and Cultural Organisation written by wellinformed Americans.

\section{Durban Museum and Art Gallery}

The annual report of the Durban Museum and Art Gallery for the year 1945-46 again stresses the need of these expanding institutions for extra space. "Ihe congested conditions," it is stated, "become more acute each year." Though the City Council has allocated several extra rooms in the municipal building for museum purposes, it is pointed out that this will only relieve the position as regards workroom, storage and library accommodation, the urgent need for further exhibition space remaining a matter which requires serious consideration. The total number of visitors to the Museum and the Art Gallery during the year was 166,922 and 154,397 respectively.

\section{Announcements}

The Ernst Julius Cohen Memorial Lecture of the Chemical Society will be given by Prof. F. G. Donnan at the rooms of the Chemical Society, Burlington House, London, W.1, on October 2 at 7.30 p.m.

DR. J. A. B. Sмгтн, lecturer in applied biochemistry with special reference to nutrition at the University of Glasgow, has been appointed deputy director of the Hannah Dairy Research Institute.

The Melehett Medal for 1947 of the Institute of Fuel has been awarded to Major Kenneth Gordon, who will deliver his Melchett Lecture on "Hydrogenation in the Fuel and Chemical Industries" at 2.30 p.m. on October 16 at Gas Industry House, 1 Grosvenor Place, London, S.W.1.

THE selection committee of the Harrison Memorial Fund, consisting of the presidents of the Chemical Society, the Royal Institute of Chemistry, the Society of Chemical Industry and the Pharmaceutical Society, will make an award of the Harrison Memorial Prize in December 1947. The Prize, not exceeding $£ 150$, will be awarded to a chemist of either sex, who is a natural-born British subject and not at the time more than thirty years of age, for original investigations published during the past five years. Communications relating to the award must be received by the President, Chemical Society, Burlington House, Piccadilly, London, W.1, not later than December 1.

The Meldola Medal is the gift of the Society of Maccabæans and is normally awarded annually. The next award will be made early in 1948 to the chemist who, being a British subject and less than thirty years of age at December 31, 1947, shows the most promise, as indicated by published chemical work brought to the notice of the Council of the Royal Institute of Chemistry before that date. Communications, either by persons who desire to recommend a candidate or by a candidate himself, should be sent to the President, Royal Institute of Chemistry, 30 Russell Square, London, W.C.1, the envelope being marked "Meldola Medal".

The Library of the joint institutions, the Botanical Garden and Institute, and the Cryptogamical Laboratory, Pavia (founded in 1871, the world's oldest laboratory devoted to the study of plant diseases), a centre for studies on fungicides, for human and comparative mycopathology (botanical section), and for mushroom culture, wishes to exchange biological and general scientific periodicals and reprints with English institutions. Almost complete series of $A t t i$ (43 volumes, from 1888 on) and Archivio Botanico (22 volumes, from 1925 on) are still available, as well as reprints of the same periodicals, and of $M y c o p a t h o l o g i a$ and $I l$ Farmaco. The Library is also a consulting library of the University of Pavia. Communications should be addressed to the Director, P.O. Box 165, Pavia, Italy.

Erratum.-In Nature, September 6, p. 326, col. 2, the name of the new assistant superintendent of the Zoological Gardens, London, should be Mr. George S. Cansdale. 